\title{
IMMUNOLOGICAL STUDIES IN PATIENTS WITH PNEUMOCOCCUS TYPE III PNEUMONIA TREATED WITH SUL- FANILAMIDE AND SERUM
}

\author{
By MAXWELL FINLAND AND JOHN W. BROWN \\ (From the Thorndike Memorial Laboratory, Second and Fourth Medical Services (Harvard), \\ Boston City Hospital, and the Department of Medicine, Harvard Medical \\ School, Boston)
}

(Received for publication January 31, 1939)

During the past season (November 1937 to May 1938) we had an opportunity to study the immune reactions of a group of patients with Pneumococcus Type III pneumonia before and during treatment with sulfanilamide and typespecific antipneumococcal rabbit serums used separately or in combination. Observations were also made on the effect of these substances, in vitro, on the bactericidal action of the blood of the patients taken before treatment. In this paper we present the results of these tests and attempt to correlate them with the course of the disease. Clinical results are reported in a separate communication (1).

The irregular and atypical response of animals to immunization with Type III pneumococci has been reported by a number of workers (2). The antibody response of human beings to Type III pneumococcal pneumonia (3) or to immunization with the specific carbohydrate of this type (4) is quite similar to that of other common pneumococcal types $(3,4)$. The blood of many normal adults and children has bactericidal properties against the Type III pneumococcus (5). This bactericidal power is inhibited by the type-specific capsular polysaccharide and is enhanced by specific antiserum $(5 a, 6)$. The latter can also neutralize the antibactericidal action of the specific carbohydrate when used in proper concentrations (6).

Robertson and his coworkers (7) studied the pneumococcidal-promoting action of the serum of 3 patients during the course of Type III pneumonia. There was some activity on the first or second day in each instance. One patient had a negative blood culture throughout the course of the disease and recovered. A second patient with less pneumococcidal-promoting activity in the serum had a positive blood culture on the first and second days. Subsequent blood cultures were sterile; there was an increase in the pneumococcidal-promoting action of the serum and recovery. The third patient had a high titer of the pneumococcidal-promoting antibody and a sterile blood culture at $\mathbf{4 8}$ hours, but beginning the following day the blood culture became and remained positive and the antibody was no longer demonstrable, the bacteremia increased and the patient died.
Sulfanilamide has been shown to have bacteriostatic and bactericidal action on Type III pneumococci in vitro (8). Experimental infections with this organism in rats and mice have been successfully treated with the drug (9). Favorable clinical results in small groups of cases of Type III pneumococcal pneumonia have been reported (10). There were no successfully treated bacteremic cases except 3 recorded by Bullowa (11).

\section{MATERIALS AND METHODS}

The patients chosen for study each had clinical and $x$-ray or pathological evidence of pneumonia and Type III pneumococci were identified in one or more specimens of sputum by the Neufeld method (12) and/or isolated after mouse inoculation. Some had typical lobar pneumonia while in others the pulmonary consolidation was atypical in distribution (bronchopneumonia). The non-pneumonic subjects were either laboratory workers or hospital patients free of febrile disease. Blood for culture and for the immunological studies was taken before treatment was begun and at suitable intervals thereafter. For the cultures, 5 to $10 \mathrm{cc}$. of blood were taken directly into $100 \mathrm{cc}$. of suitable broth at the bedside and, in addition, $3 \mathrm{cc}$. were taken in sterile 2.5 per cent citrate solution and agar plates were poured with 1 and $2 \mathrm{cc}$. of blood as soon as possible after it reached the laboratory. The immunological methods were similar to those used in previous studies (13). In the pneumococcidal tests $(5 a)$ the sealed tubes containing the defibrinated blood, pneumococci, and other added ingredients were observed at 24 and 48 hours and changes in the color of the blood noted. At the end of this period the tube containing the smallest number of pneumococci with which the blood exhibited color change and all those in which the blood remained unaltered were broken open and cultured on the surface of blood agar plates, in agar pour plates, and frequently also in rabbit's blood broth. Absence of color change was taken to indicate bacteriostasis, and failure to obtain pneumococci on culture was considered to indicate bactericidal activity. One of the tubes in each test was inoculated with $0.1 \mathrm{cc}$. of the original culture and allowed to rotate in the incubator for one hour, after which smears were made of its contents and stained with Wright's blood stain. The number of diplococci in 50 consecutive polymorphonuclear leukocytes were counted and the percentage of these cells containing diplococci was noted $(6 c)$. The average num- 
ber of diplococci per polymorphonuclear leukocyte is referred to as the phagocytic index.

The Rockefeller Institute strain of Type III pneumococcus in use in this laboratory for several years was employed throughout this study. It was passed through mice almost daily. The cultures used were second or third subcultures of mouse heart's blood in rabbit's blood broth in the lag phase of growth, either after 10 hours' growth with a small inoculum or, when necessary for the pneumococcidal test, after 4 or 5 hours' growth with a 50 per cent inoculum. Pour plates yielded 35 to 120 colonies per cc. of the original culture. The virulence was such that either one or both of 2 mice inoculated with $10^{-9} \mathrm{cc}$. invariably died within 48 hours.

Sulfanilamide determinations in the blood were carried out by the method of Marshall (14). The drug was given to the patients by mouth in divided doses, usually at 4-hour intervals.

The therapeutic immune rabbit serums used were mostly experimental lots of concentrated serums prepared and furnished by the Lederle Laboratories, Inc. The potency of some of these preparations was estimated at 1000 to 5000 units, the unit being defined as 10 times the least amount which protects 50 per cent of mice against 100 fatal doses. No estimations were made on some of the lots. One preparation of unconcentrated serum was furnished by the Massachusetts Antitoxin and Vaccine Laboratory.

\section{RESULTS}

Effect of sulfanilamide on the pneumococcidal action of blood in non-pneumonic subjects (Table $I)$. Defibrinated blood of 9 subjects was tested. In 6 instances the sulfanilamide was added to the blood in vitro in amounts sufficient to make the desired concentration and tested simultaneously with the control blood containing no sulfanilamide. In the 3 remaining subjects a second blood was taken after each had received 10 grams of the drug in divided doses (4 hours after the last dose). The concentration of the unconjugated sulfanilamide in the second blood was 7.6 to 8.5 mgm. per $100 \mathrm{cc}$.

As was to be expected, most of the subjects had some pneumococcidal power in the control blood. Growth or killing in these bloods was complete

TABLE I

Effect of sulfanilamide on the phagocytic and preumococcidal activity of defibrinated blood against Type III pneumococci in persons without pneumonia

\begin{tabular}{|c|c|c|c|c|c|c|c|c|c|}
\hline \multirow{3}{*}{ Sub- } & \multicolumn{3}{|c|}{ Control tests without sulfanilamide } & \multicolumn{6}{|c|}{ Tests with sulfanilamide } \\
\hline & \multicolumn{2}{|c|}{ Phagocytosis } & \multirow{2}{*}{$\begin{array}{l}\text { Pneumo- } \\
\text { cocci } \\
\text { killed } \\
\text { per } 0.5 \mathrm{cc} . \\
\text { of bloodt }\end{array}$} & \multirow{2}{*}{$\begin{array}{l}\text { Concen- } \\
\text { tration } \\
\text { of free } \\
\text { sulfanil- } \\
\text { amide }\end{array}$} & \multicolumn{2}{|c|}{ Phagocytosis } & \multirow{2}{*}{\multicolumn{2}{|c|}{$\begin{array}{l}\text { Inhibition of growth } \\
\text { (absence of color change) }\end{array}$}} & \multirow{2}{*}{$\begin{array}{c}\text { Pneumo- } \\
\text { cocci } \\
\text { killed } \\
\text { per } 0.5 \mathrm{cc} \\
\text { of blood }\end{array}$} \\
\hline & $\begin{array}{c}\text { Average } \\
\text { number of } \\
\text { diplococci per } \\
\text { polymorpho- } \\
\text { nuclear } \\
\text { leukocyte }\end{array}$ & $\begin{array}{c}\text { Per cent of } \\
\text { polymorpho- } \\
\text { nuclear } \\
\text { leukocytes } \\
\text { phagocyting }\end{array}$ & & & $\begin{array}{c}\text { Average } \\
\text { number of } \\
\text { diplococci per } \\
\text { polymorpho- } \\
\text { nuclear } \\
\text { leukocyte }\end{array}$ & $\begin{array}{c}\text { Per cent of } \\
\text { polymorpho- } \\
\text { nuclear } \\
\text { leukocytes } \\
\text { phagocyting }\end{array}$ & & & \\
\hline McD. & 0 & 0 & 0 & $\begin{array}{c}\text { (mgm. per } \\
100 \text { cc.) } \\
10.0\end{array}$ & 0.06 & 6 & $10^{4}$ & 10 & 0 \\
\hline $\mathbf{M}$. & 0.1 & 8 & 0 & $\begin{array}{r}5.0 \\
10.0 \\
15.0 \\
20.0\end{array}$ & $\begin{array}{l}0.04 \\
0.02 \\
0.02 \\
0\end{array}$ & $\begin{array}{l}4 \\
2 \\
2 \\
0\end{array}$ & $\begin{array}{l}10 \\
10^{4} \\
10^{5} \\
10^{5}\end{array}$ & $\begin{array}{c}0 \\
10^{2} \\
10^{2} \\
10^{4}\end{array}$ & $\begin{array}{l}0 \\
0 \\
0 \\
0\end{array}$ \\
\hline R. & 0.06 & 6 & $10^{4}$ & 10.0 & 0.01 & 4 & $10^{5}$ & & $10^{5}$ \\
\hline F. & 0 & 0 & $10^{5}$ & 10.0 & 0.06 & 4 & $10^{6}$ & & $10^{6}$ \\
\hline L. & 0.04 & 4 & 0 & $7.6^{*}$ & 0.08 & 2 & $10^{4}$ & & 0 \\
\hline B. & 0.6 & 32 & $10^{3}$ & $8.5^{*}$ & 0.40 & 28 & $10^{5}$ & & $10^{4}$ \\
\hline M. & 0.1 & 10 & $10^{4}$ & $8.3^{*}$ & 0.10 & 8 & $10^{6}$ & & $10^{4}$ \\
\hline
\end{tabular}

* Blood taken after 10 grams were given by mouth during previous 24 hours. In others, sufficient sulfanilamide was added to the blood in $0.1 \mathrm{cc}$. of saline (in vitro) to make the desired concentration.

+ Color change (growth inhibition) at 24 and 48 hours corresponded in each instance. 
within 24 hours. In the 3 subjects lacking pneumococcidal activity, the addition of sulfanilamide in amounts to make 7.6 or more mgm. per $100 \mathrm{cc}$. resulted in definite inhibition of growth for 24 hours with inocula up to 10,000 organisms. Larger concentrations of the drug increased and prolonged the bacteriostatic effect. No bactericidal effect was noted. In the subjects possessing pneumococcidal activity in the control blood, the addition of sulfanilamide enhanced this property only slightly or not at all. Practically no phagocytosis was observed in any of the control tests. The addition of sulfanilamide had no effect on phagocytosis.

Patients possessing pneumococcidal activity before treatment (Table II). There were $11 \mathrm{pa}$ tients in whom the initial blood taken before treatment was bactericidal for Type III pneumococci.
In only one instance (D. M.) was this property associated with demonstrable agglutinins and mouse protective antibody. This patient was also the only one with blood exhibiting any appreciable phagocytic activity before treatment. Crisis occurred within 24 hours after only 4 grams of the drug had been given. In vitro tests performed on the preliminary bloods of the 11 patients after addition of sulfanilamide gave results similar to those obtained in normals. The addition of specific serum increased the pneumococcidal activities of these bloods.

Sulfanilamide alone was used in the treatment of 7 of these patients. Later bloods showed the same or greater pneumococcidal power. Agglutinins and mouse protective antibodies were demonstrated in subsequent serums in 6 of these cases. Two of these patients died, one (P. F.) on the

TABLE II

Patients with Pneumococcus Type III pneumonia whose blood was bactericidal for Type III pneumococci before treatment was begun

\begin{tabular}{|c|c|c|c|c|c|c|c|c|c|}
\hline \multirow{2}{*}{ Name } & \multirow{2}{*}{ Sex } & \multirow{2}{*}{ Age } & \multirow{2}{*}{$\begin{array}{l}\text { Results } \\
\text { of blood } \\
\text { cultures* }\end{array}$} & \multirow{2}{*}{$\begin{array}{l}\text { Day } \\
\text { treat- } \\
\text { ment } \\
\text { begun }\end{array}$} & \multirow{2}{*}{$\begin{array}{l}\text { Pneu- } \\
\text { mococ- } \\
\text { cidal } \\
\text { action } \\
\text { before } \\
\text { treat- } \\
\text { mentt }\end{array}$} & \multirow{2}{*}{ Treatment } & \multicolumn{2}{|c|}{$\begin{array}{c}\text { Termination } \\
\text { of disease }\end{array}$} & \multirow{2}{*}{ Remarks } \\
\hline & & & & & & & Mode & Day & \\
\hline P. F. & $\mathbf{M}$ & $\begin{array}{c}\text { years } \\
65\end{array}$ & $\begin{array}{l}\text { Pn. III-6; } \\
\text { Neg.-7, 8; } \\
\text { S. aureus- } \\
9,13\end{array}$ & 8 & $10^{5}$ & Sulfanilamide & Death & 13 & $\begin{array}{l}\text { Death apparently due to } S \text {. aureus sepsis after developing } \\
\text { agglutinins and mouse protective antibodies for Pn. III }\end{array}$ \\
\hline J. R. & $\mathbf{M}$ & 67 & $\mathrm{Neg}_{\mathrm{A}}^{\mathrm{N}}-\mathbf{3}, \mathbf{4}$ & 3 & 104 & Serum & Death & 7 & $\begin{array}{l}\text { Extended after treatment in spite of good titer of agglutinins } \\
\text { and protective antibody; Pn. III, S. hemolyticus and } S \text {. aureus } \\
\text { in lungs at autopsy }\end{array}$ \\
\hline A. F. & $\mathbf{M}$ & 5 & Neg.-6, 7 , & 6 & $10^{4}$ & Sulfanilamide & Death & 14 & $\begin{array}{l}\text { Lungs }=S . \text { hemolyticus, } S \text {. aureus and } H \text {. influensae (no Pn.). } \\
\text { No agglutinins or protection on 8th day (last test) }\end{array}$ \\
\hline C. $\mathbf{N}$. & F & 43 & $\begin{array}{l}\text { Neg. }-5,7, \\
9,10,11 ; 8 \\
\text { Pn. III }-8\end{array}$ & 9 & 105 & Sulfanilamide & Lysis & $9-10$ & $\begin{array}{l}\text { Blood culture sterile before first dose had agglutinins and } \\
\text { protection } 2 \text { days later }\end{array}$ \\
\hline D. $\mathbf{M}$. & F & 16 & Neg.-2 (?) & 3 & 10 & Sulfanilamide & Crisis & 4 & $\begin{array}{l}\text { Agglutinins and protection present on third day (Pneumonia } \\
\text { may have begun } 4 \text { days earlier) } \delta\end{array}$ \\
\hline J. A. & $\mathbf{M}$ & 18 & Neg. $-5,6$ & 5 & 105 & Sulfanilamide & Crisis & 8 & Developed protective antibody and agglutinins \\
\hline T. P. & $\mathbf{F}$ & 53 & Neg, $-4,5$, & 4 & $10^{3}$ & Sulfanilamide & Crisis & 5 & Developed protective antibody and agglutinins \\
\hline R. W. & $\mathbf{F}$ & 41 & Neg.-3, 4, 5 & 3 & 104 & Sulfanilamide & Crisis & 5 & Developed protective antibody and agglutinins \\
\hline E.S. & $\mathbf{F}$ & 55 & $\mathrm{Neg}_{4,7}-2,3$ & 3 & 106 & $\begin{array}{l}\text { Serum and } \\
\text { sulfanilamide }\end{array}$ & Lysis & $8+$ & Transient balance of protective antibody after treatment \\
\hline R. G. & F & 45 & Neg:-3, $-3,11,12$ & 4 & $10^{5}$ & $\begin{array}{l}\text { Serum and } \\
\text { sulfanilamide }\end{array}$ & Crisis & 8 & $\begin{array}{l}\text { Nonprotein nitrogen }=48,90,55 \text { and } 35 \mathrm{mgm} \text {. per } 100 \mathrm{cc} \text {. on } \\
\text { Days } 4,7,11 \text {, and } 16, \text { respectively. Balance of agglutinins } \\
\text { and protection maintained }\end{array}$ \\
\hline M. N. & $\mathbf{M}$ & 60 & Neg.-1, 2 & 1 & 104 & $\begin{array}{l}\text { Serum and } \\
\text { sulfanilamide }\end{array}$ & Crisis & 2 & $\begin{array}{l}\text { Balance of agglutinins and protection established and main- } \\
\text { tained }\end{array}$ \\
\hline
\end{tabular}

* Numbers represent days of the disease.

$\dagger$ Number of diplococci killed in 0.5 cc. of blood.

$\S$ This is the only patient with appreciable phagocytic titer before treatment (1.88 diplococci per polymorphonuclear leukocyte).

$\ddagger \mathbf{A}=$ Autopsy. 
13th and the other (A. F.) on the 14th day. The former had a positive blood culture for Type III pneumococcus on the sixth day but 2 subsequent cultures taken prior to treatment were sterile. Following treatment the patient developed Staphylococcus aureus bacteremia and died. In Patient A. F. no tests were done after the 8th day. Blood cultures before and after the beginning of treatment and at autopsy were all sterile. The lungs showed bronchopneumonia and cultures showed hemolytic streptococci, Staphylococcus aureus, and influenza bacilli, but no pneumococci. One of the patients who recovered (C. N.) had a positive blood culture on the eighth day but the culture taken the next day just before treatment was begun was sterile.

Specific antiserum alone or with sulfanilamide was used in the treatment of the remaining 4 patients. All had negative blood cultures throughout and developed and maintained a balance of agglutinins and protective antibody in the blood after treatment. One of these patients (J. R.) died. He received no sulfanilamide, and the lesion in the lung extended after serum administration in spite of negative blood cultures and a balance of agglutinins and mouse protective antibodies. Type III pneumococci were recovered from both lower lobes and, in addition, hemolytic streptococci and Staphylococcus aureus were cultured from one of the lobes.

In general, therefore, patients with pneumococcidal activity in their blood during the disease and before treatment developed homologous typespecific agglutinins and mouse protective antibodies following sulfanilamide therapy and either recovered or died with secondary infections associated with other organisms. The only patient in whom such antibodies were not demonstrated was A. F. In this patient no tests were done after the eighth day and death associated with a superinfection occurred 6 days later, during which time specific antibodies may have developed. In the 2 bacteremic patients (A. F. and C. N.) the pneumococcal infection was apparently overcome at the time treatment with sulfanilamide was instituted. Following treatment with specific serum, a balance of agglutinins and protective antibodies was readily established.

Patients lacking pneumococcidal activity in their blood before treatment (Table III). In 15 of the
26 patients tested, the defibrinated blood taken before treatment failed to kill any Type III pneumococci or killed only the smallest number ( 4 to 10 organisms) inoculated into $0.5 \mathrm{cc}$. of the blood. Phagocytosis, agglutinins, and passive protection of mice could not be demonstrated in any instance.

In vitro tests of the effect of serum and sulfanilamide were carried out with the blood taken before treatment. The addition of sulfanilamide to a final concentration of $1: 10,000$ (10 mgm. per $100 \mathrm{cc}$.) resulted in marked bacteriostasis in 12 of 14 cases tested. Growth inhibition was apparent at 24 hours with inocula of 100,000 and $1,000,000$ organisms and was still effective with the same or slightly smaller inocula after 48 hours' incubation in 10 of the tests. This bacteriostatic effect was manifest even in bloods from which pneumococci were cultured in large numbers (Cases D. B. and M. W.). Actual killing of some pneumococci after the addition of sulfanilamide occurred in 3 instances (and possibly in 4 others in whom blood agar streak plates showed no growth but pour plates were not made with the blood containing the smaller inocula), but it was always of low grade. Only 100 or 1000 pneumococci were killed in these bloods. Phagocytosis was not enhanced by the addition of sulfanilamide. In Case M. W. the addition of sulfanilamide to a concentration of 15 or $20 \mathrm{mgm}$. per $100 \mathrm{cc}$. resulted in somewhat greater inhibition, and 10,000 and 100,000 pneumococci, respectively, were killed. In the same blood, a concentration of $5 \mathrm{mgm}$. per $100 \mathrm{cc}$. of sulfanilamide. had no effect.

The addition of therapeutic rabbit serums to a final dilution of from $1: 60$ to $1: 300$ resulted in the killing of from 100 to 100,000 pneumococci in $0.5 \mathrm{cc}$. of the blood of all but 4 of the patients. In 3 of the latter 4 cases there was heavy blood stream invasion. In some instances free growth of organisms was inhibited for the first 24 hours in the blood containing large numbers of inoculated pneumococci. The addition of the same amount of serum together with sulfanilamide to a concentration of $10 \mathrm{mgm}$. per $100 \mathrm{cc}$. resulted quite regularly in an increased bacteriostatic and bactericidal action as compared with either serum or sulfanilamide alone. Phagocytosis was definitely enhanced only in the presence of serum, and the addition of sulfanilamide produced no added effect. In the phagocytic mixtures contain- 
ing the larger amounts of serum, the results were often obscured by the agglutination of pneumococci and of leukocytes and the injury to the latter in making the smears. This rendered the satisfactory estimation of phagocytosis impossible.

In summary, the addition of sulfanilamide to the blood of patients lacking bactericidal action resulted fairly regularly in moderate to marked bacteriostasis. Occasionally there was some bactericidal action but no phagocytosis occurred. Immune serum, on the other hand, induced bactericidal action and frequently phagocytosis as well. The combination of serum and sulfanilamide resulted in marked bacteriostasis and better bactericidal action than when either was used alone in the same amount.

Tests were done after treatment with serum. alone in 4 cases, after the administration of sulfanilamide alone in 2 cases, and after both had been given in 8 cases. The results may be summarized for each of these 3 groups.

After serum alone. One patient, R. F., received $40 \mathrm{cc}$. of serum on the fourth day, after which no antibodies could be demonstrated by any of the tests. The blood culture before treatment was sterile but those taken on the next 2 days showed large numbers of Type III pneumococci, and the patient died. The addition of serum to his blood before treatment failed to induce pneumococcidal activity. The second patient, F. S., received 150 and $60 \mathrm{cc}$. of serum, respectively, on the sixth and seventh days, following which the blood showed marked pneumococcidal action, irregular agglutinins and mouse protective antibodies, and no phagocytosis. Sulfanilamide was administered during the next 2 days but no further tests were done. Blood cultures were negative before and after treatment, and the patient died. Patients J. T. and E. J. received 60 and $100 \mathrm{cc}$. of antiserum, respectively, on the fifth day of the disease and recovered. Pneumococcidal activity and mouse protective antibody were present after this treatment, and there was transient appearance of agglutinins and phagocytosis.

After sulfanilamide alone. Both patients, A. S. and Ma.McC., recovered without developing demonstrable antibodies. Blood cultures were negative in each case. The blood of $\mathrm{Ma}$. McC. showed growth inhibition when the concentration of free sulfanilamide was 6.9 but not at the lower level of $2.1 \mathrm{mgm}$. per cent. The pneumonia in Patient A. S. was atypical with only slight pulmonary involvement.

After serum and sulfanilamide. Patient $M$. McC. received sulfanilamide for 2 days during which his blood showed only growth inhibition. Following the administration of serum and further doses of sulfanilamide sufficient to raise the blood concentration of the drug, there was some pneumococcidal activity. There was a transient balance of mouse protective antibody but no agglutinins or phagocytosis could be demonstrated, and the patient died. Blood cultures were positive before and sterile after serum treatment. Four other patients in this group died. Two of them, F. I. and F. M., showed only growth inhibition in their blood but no bactericidal action, phagocytosis, agglutinins, or mouse protective antibody. The other 2 each developed a good balance of antibodies measurable by all of the tests. One of them, C. S., developed a hemiplegia on the second day after an apparent crisis and died 2 days later; the other had a prolonged course and died on the 24th day. All 5 of these fatal cases had Type III pneumococcus bacteremia. In Patient C. S., no pneumococci could be cultured at autopsy and in Patient M. W. there were multiple abscesses in the lung which yielded Type III pneumococcus and Staphylococcus aureus, but blood cultures taken after treatment were sterile.

In two non-bacteremic patients, L. T. and J. S., prompt crisis occurred following treatment, and antibodies were demonstrable by all the tests.

The last patient, J. K., is of especial interest. He received $2 \mathrm{cc}$. of antiserum on the second day. No further serum was given because of a severe chill with rise in temperature to $107^{\circ} \mathrm{F}$. Blood cultures before this dose and on the following day, before sulfanilamide therapy was begun, were both positive for Type III pneumococcus. Following treatment with the drug, the blood exhibited a bacteriostatic action and, on one occasion, also showed some bactericidal activity. No other antibodies could be demonstrated before or later although the patient recovered by crisis on the day after sulfanilamide therapy was begun.

In summary, when a balance of antibody demonstrable by agglutination, mouse protection, or phagocytosis was established and maintained, the patients, in general, apparently recovered from 


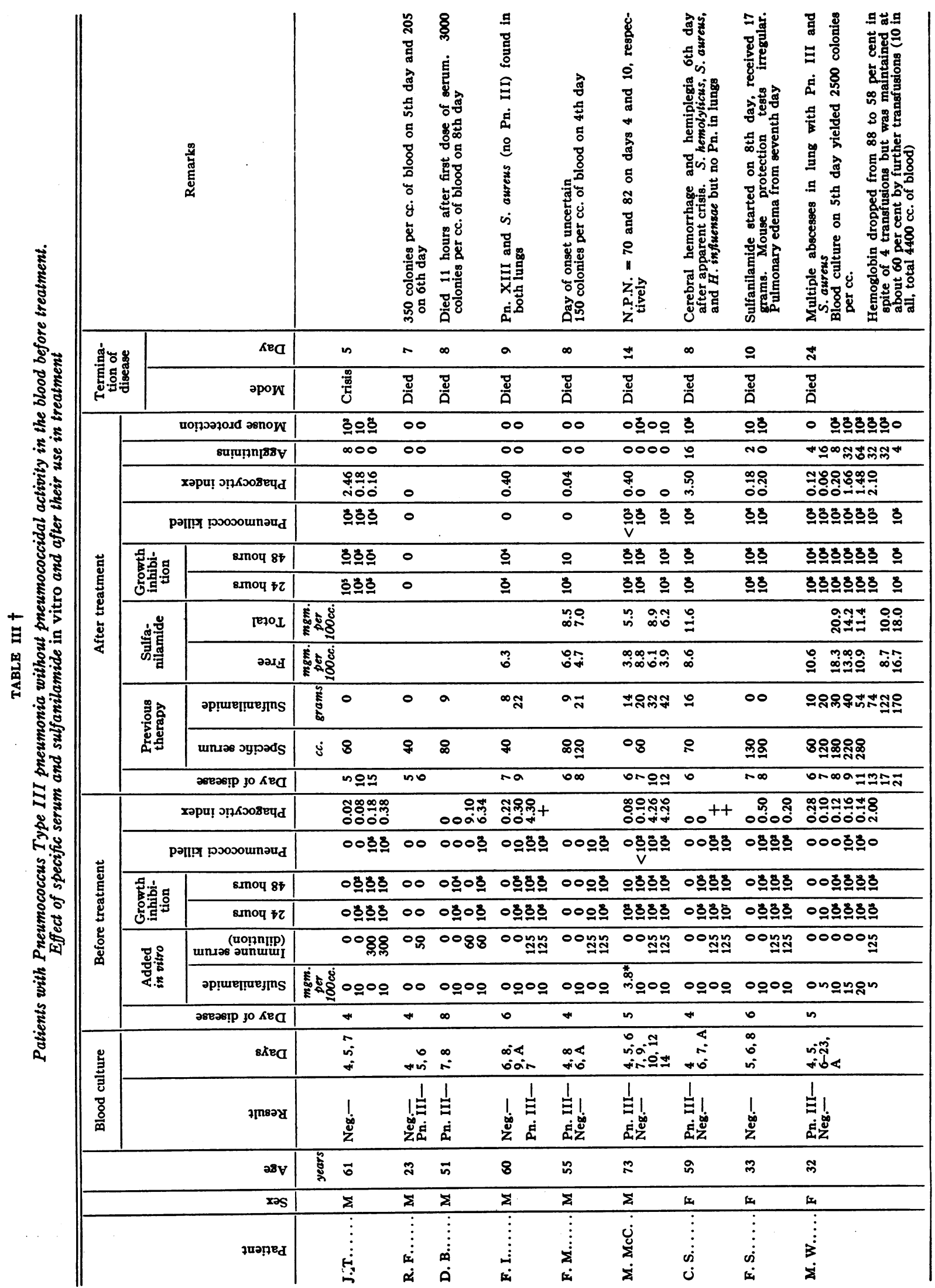




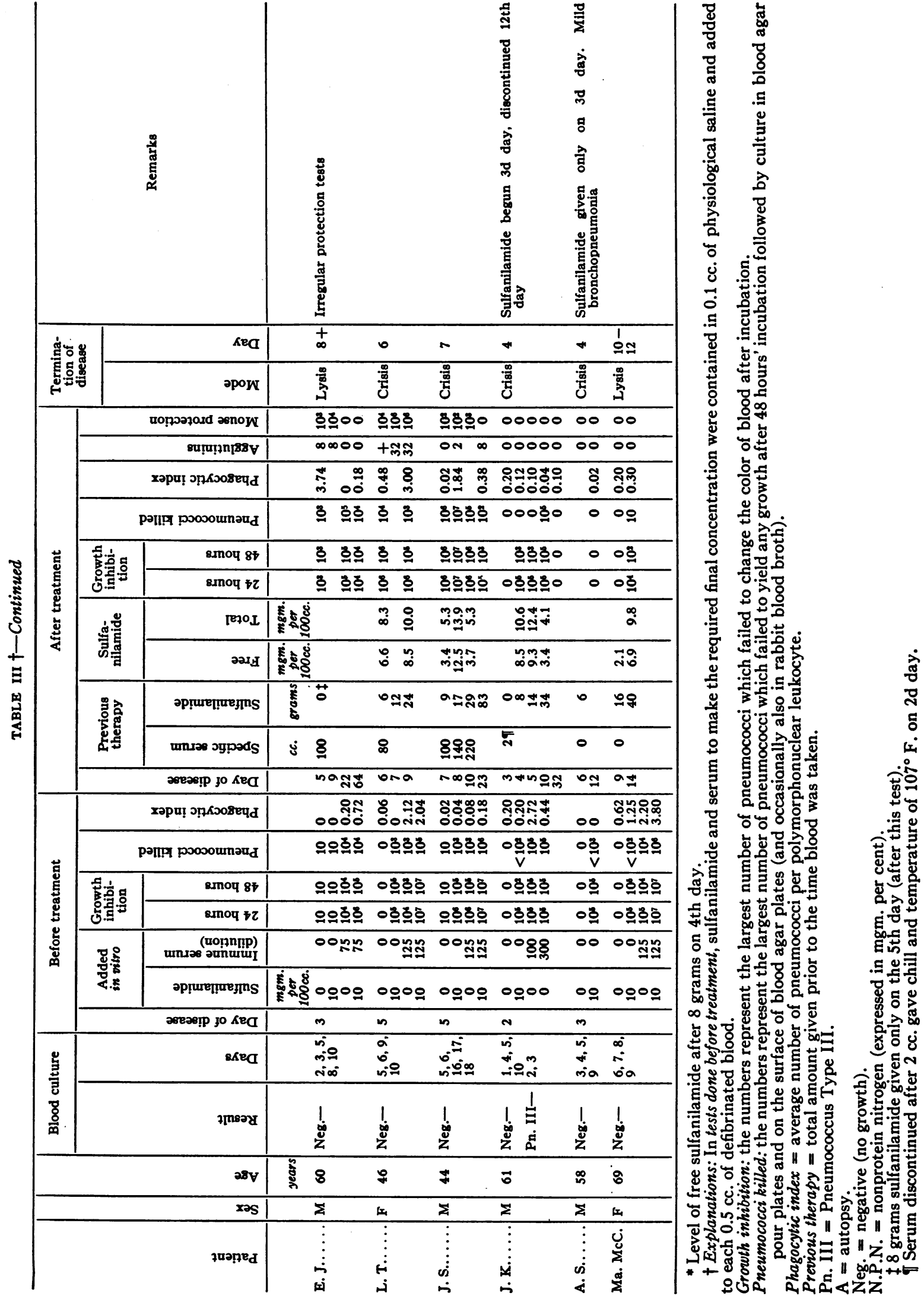


the pneumococcal infection. If death occurred it was associated with complications of the pneumonia or with conditions not directly related to the pneumococcal infection. In 3 patients treated with sulfanilamide alone recovery was not associated with demonstrable antibodies. One of these patients had mild atypical pneumonia and 2 had sterile blood cultures. The third had bacteremia and received a small dose of serum which had no apparent effect on the immune status, either by virtue of the antibody or because of the elevated temperature that resulted (15), since bacteremia was still demonstrated on the day after the high fever and no antibodies were found.

Three other patients are of interest but are not included in the table because pneumococcidal tests were not carried out. The first was a 47-year-old man who started on sulfanilamide therapy on the sixth day. No agglutinins or mouse protective antibodies could be demonstrated following treatment, and the patient died on the 13th day. Blood cultures taken before treatment were sterile and later ones were positive. The second patient was a boy of 17 who received $40 \mathrm{cc}$. of specific antiserum on the third day after which agglutinins $(1: 32)$ and mouse protection (against 1,000,000 fatal doses in $0.2 \mathrm{cc}$. of serum) were demonstrated in his blood and there was a prompt crisis within 6 hours of the time the first dose was given. Preliminary blood culture was sterile. The third patient, a man 66 years old, had a negative blood culture on the third day. On the following day sulfanilamide therapy was begun and the blood culture taken before the first dose was positive for Type III pneumococcus. Subsequent blood cultures were sterile, agglutinins $(1: 4)$ and protection (against 1000 fatal doses) were demonstrated in the patient's serum on the seventh day and later, and he recovered.

\section{DISCUSSION}

The results of the present studies indicate that in human blood, sulfanilamide, either when added in vitro or when absorbed after ingestion, inhibits the free growth of large numbers of virulent Type III pneumococci. Concentrations of about 7 mgm. per $100 \mathrm{cc}$. or higher are apparently necessary for this bacteriostatic action. The drug usually has no bactericidal effect on pneumococci of this type even in concentrations up to $20 \mathrm{mgm}$. per cent. The same growth inhibition occurs in the blood of non-infected individuals and in the blood of patients with Pneumococcus Type III pneumonia during the acute disease. Neither this growth inhibition nor the bactericidal activity when it occurs are associated with any marked degree of phagocytosis as demonstrated by the test employed here. Type-specific antipneumococcal rabbit serums usually enhance the pneumococcidal power of blood and this activity is usually associated with phagocytosis. The combination of sulfanilamide and type-specific serum is more effective than either of these agents used separately in promoting bacteriostasis and pneumococcidal activity in the fresh defibrinated blood of patients during the acute disease.

It is not surprising that bactericidal activity was not induced with specific antiserum in the blood of some patients acutely ill with Type III pneumococcus pneumonia. In the first place, the potency of the serums used was unknown and was frequently low. These therapeutic Type III rabbit serums were among the early lots produced and experimental methods were used in immunization of the animals and in concentration of the serums. Also, no attempts were made to rule out any prozone phenomenon in the tests (6b). The patients in whose blood the antiserums failed to induce bactericidal action were heavily infected and may have required relatively large amounts of antibody to neutralize the antibactericidal substances presumably present in the blood. This factor was not controlled in the present studies. The leukocytes were not at fault quantitatively, since adequate numbers were found in the defibrinated blood at the time of each test. It is not possible to rule out functional failure of the leukocytes either as a result of the disease or through the action of the carbohydrate-anticarbohydrate combination present in the blood at the time of the tests (16). The more recent lots of rabbit serums that we have had available have been more potent in terms of units and more effective both in the test tube experiments and in the regularity with which a balance of antibodies could be established in the treated patient.

The phagocytic test as employed here is a rather severe one and it is not surprising that this test correlated better with the presence of heat-stable 
antibodies (agglutinins and mouse protective antibody) than with the more sensitive pneumococcidal test. The inoculum in $0.5 \mathrm{cc}$. of blood contained, in addition to approximately $100,000,000$ pneumococci, $0.1 \mathrm{cc}$. of the original culture fluid. This contained a considerable amount of specific antibactericidal material $(6 \mathrm{~b})$ in the form of the capsular polysaccharide. It was necessary to have enough antibody to neutralize the action of the carbohydrate and a sufficient excess to promote phagocytosis. Agglutination interfered with the in vitro tests but the phagocytosis was usually discernible in mixtures in which this reaction occurred.

It appears from the findings presented that recovery from Type III pneumococcus pneumonia, as in other types, is usually associated with the development of heat stable antibodies demonstrable by agglutinins, mouse protection, and by phagocytosis in fresh blood. Occasional patients did recover, however, without demonstrable antibodies. In view of the frequency with which the Type III pneumococcus is found in the normal nasopharynx and particularly in the nasal secretions and the sputum of persons with chronic respiratory infections, the possibility arises that in such cases the finding of this organism is only incidental and that it is not the true incitant of the pneumonia in the given case. In 2 of the patients (Ma. McC. and A. S.), who recovered without developing type-specific antibodies, this possibility can not be ruled out since there was only a mild atypical pneumonia in one, blood cultures were sterile in both, and the Type III pneumococci were obtained only from purulent sputum in each instance. However, in the third patient, J. K., bacteremia was present and yet recovery occurred without antibodies. To be sure, there was some bactericidal activity on one occasion after recovery at a time when the concentration of sulfanilamide was low, but no other antibodies were found. This suggests that in these cases either recovery took place without the development of heat stable antibodies, or that such antibodies were only transient so that they appeared and disappeared between the times the tests were made, or antibodies developed against the homologous strain but could not be demonstrated with the stock strain used. The two latter explanations need not necessarily be invoked in view of the known vari- ability with which different animals respond to immunization with Type III pneumococci (2).

It may be inferred from the present findings that whatever therapeutic activity sulfanilamide may have is probably due to its bacteriostatic effect. If the patient had pneumococcidal properties in his blood, this effect may be sufficient to keep the infection localized until the natural defenses are mobilized either through the development of heat stable antibodies or by whatever mechanism may be involved when recovery occurs without such antibodies. Obviously specific antiserum should hasten such recovery unless the antigen-antibody combination can occur and produce toxic effects in vivo, or unless quantitative factors such as those operative in the prozone phenomenon can occur within the patient. Such effects have not been demonstrated, but the possibility that they may be responsible for some of the immediate untoward effects of serum therapy might be considered. If these effects do occur it should be possible to avoid them by controlling the speed of administration of antibody in the severely infected patient. However, it is not proper to infer from the closed system involved in the test tube experiment that these ill effects take place in the circulating blood or tissues of the patient.

If the patient fails to develop antibodies or to receive such antibodies passively, blood invasion may occur in spite of sulfanilamide therapy and death may ensue. A consideration of some of the pathological features $(17,18)$ and of some of the host factors $(17,19)$ frequently involved in cases of Pneumococcus Type III pneumonia leaves room for adequate causes of death even when the pneumococcal infection itself is apparently overcome. Deaths in such cases may be due to systemic diseases, to late complications of the pneumonia or to super-infections with other organisms. All of these conditions have been noted in the present group of cases.

The failure of macrophages to appear in the consolidated lung has been offered as an explanation of the local spread of the disease and of death in patients who have circulating antibodies (20). Such a mechanism may have been involved in one of the present cases (J.R.). In this patient pneumococcidal activity was present in the blood before treatment with specific serum. Following treat- 
ment the lesion extended to the opposite lung, in spite of the fact that the bactericidal action persisted and a balance of agglutinins and mouse protective antibodies was established and maintained and blood cultures were sterile both before and after treatment. Microscopic sections of the consolidated lobes of this patient revealed only occasional macrophages, and polymorphonuclear leukocytes predominated in the exudate.

Further studies with sulfanilamide and sulfapyridine are being continued with Drs. Spring and Lowell during the present season.

\section{CONCLUSIONS}

Sulfanilamide in concentrations of $7 \mathrm{mgm}$. or more per $100 \mathrm{cc}$. inhibits the growth of large numbers of Type III pneumococci in the blood of non-pneumonic individuals or of patients ill with pneumonia due to this organism when such bloods lack pneumococcidal activity. The drug probably does not influence phagocytosis in these bloods. It usually exerts no bactericidal effect in a concentration of $10 \mathrm{mgm}$. per $100 \mathrm{cc}$., but may do so in greater concentrations.

Patients with Pneumococcus Type III pneumonia, whose blood is bactericidal for pneumococci of the homologous type during the acute disease and before treatment, usually acquire homologous type-specific agglutinins, mouse protection, and phagocytosis after treatment with either sulfanilamide or serum or both. Blood invasion does not occur after treatment in such cases and if death occurs it is usually due to superinfections or to other conditions not directly related to the Type III pneumococcal infection. In an occasional patient the pneumonia extends in spite of the presence of circulating antibodies and in spite of the absence of bacteremia throughout the disease.

Therapeutic antipneumococcal rabbit serums induce pneumococcidal activity in the blood of patients ill with pneumonia due to this type. Antiserum and sulfanilamide used together have a greater bacteriostatic and bactericidal effect than the same amounts of either the serum or the sulfanilamide used separately. The bactericidalpromoting property of the antiserum is usually accompanied by demonstrable phagocytosis.

In patients whose blood lacks bactericidal properties, treatment with sulfanilamide probably ren- ders the blood bacteriostatic until heat stable specific antibodies (agglutinins and mouse protection) develop or until a balance of such antibodies is passively introduced. When such heat stable antibodies are acquired, the pneumococcal infection is usually overcome. With antiserums in proper amounts, the infection may be overcome without the additional use of sulfanilamide, especially in patients who are not heavily infected. Death in either event may nevertheless occur, but under such circumstances it is due either to complications or to conditions not related to the Type III pneumococcal infection.

Following treatment with sulfanilamide alone, occasional patients with Type III pneumococcus pneumonia recover without developing demonstrable homologous type-specific antibodies. This may occur even if the pneumococcus is recovered from the blood stream.

The authors are indebted to Mrs. Mildred W. Barnes for technical assistance and to Dr. Edward C. Curnen for his part in the study of some of the cases.

\section{BIBLIOGRAPHY}

1. Finland, M., and Brown, J. W., Treatment of Pneumococcus Type III pneumonia with specific serum and sulfanilamide. New England J. Med., 1939, $220,365$.

2. See Finland and Winkler ( $3 b$, Reference 1 ).

3. (a) Finland, M., and Sutliff, W. D., Specific cutaneous reactions and circulating antibodies in the course of lobar pneumonia. J. Exper. Med., 1931, 54, 637.

(b) Finland, M., and Winkler, A. W., Antibody response to infections with Type III and the related Type VIII pneumococcus. J. Clin. Invest., 1934, $13,79$.

4. (a) Finland, M., and Dowling, H. F., Cutaneous reactions and antibody response to intracutaneous injections of pneumococcus polysaccharides. J. Immunol., 1935, 29, 285.

(b) Finland, M., and Ruegsegger, J. M., Immunization of human subjects with the specific carbohydrates of Type III and the related Type VIII pneumococcus. J. Clin. Invest., 1935, 14, 829.

5. (a) Ward, H. K., Observations on the phagocytosis of the pneumococcus by human whole blood. I. The normal phagocytic titer and the anti-phagocytic effect of soluble specific substance. J. Exper. Med., 1930, 51, 675.

(b) Sutliff, W. D., and Finland, M., Antipneumococcus immunity reactions in individuals of different ages. J. Exper. Med., 1932, 55, 837. 
(c) Robertson, O. H., and Cornwell, M. A., A study of the resistance of normal human beings to recently isolated strains of pathogenic pneumococci. J. Exper. Med., 1930, 52, 267.

6. (a) Sia, R. H. P., Studies on pneumococcus growth inhibition. VI. The specific effect of pneumococcus soluble substance on the growth of pneumococci in normal serum-leukocyte mixtures. J. Exper. Med., 1926, 43, 633.

(b) Ward, H. K., An examination of the mechanism of pneumococcus immunity by means of bactericidal measurements. I. The reaction between the anticarbohydrate antibody and the purified specific carbohydrate. J. Exper. Med., 1932, 55, 511.

II. The reaction between anticarbohydrate antibody and type-specific products of the organism. J. Exper. Med., 1932, 55, 519.

(c) Ward, H. K., and Enders, J. F., An analysis of the opsonic and tropic action of normal and immune sera based on experiments with the pneumococcus. J. Exper. Med., 1933, 57, 527.

7. Robertson, O. H., Terrell, E. E., Graeser, J. B., and Cornwell, M. A., The relation of natural humoral antipneumococcal immunity to the inception of lobar pneumonia. J. Exper. Med., 1930, 52, 421.

8. (a) Domagk, G., Ein Beitrag zur Chemotherapie der bakteriellen Infektionen. Deutsche med. Wchnschr., 1935, 61, 256.

(b) Rosenthal S. M., Studies in chemotherapy. III. The effects of p-aminobenzene sulphonamide on pneumococci in vitro. Pub. Health Rep., 1937, 52, 192.

9. (a) Rosenthal, S. M., Studies in chemotherapy. II. Chemotherapy of experimental pneumococcus infections. Pub. Health Rep., 1937, 52, 48.

(b) Cooper, F. B., Gross, P., and Mellon, R. R., Action of p-aminobenzenesulfonamide on Type III pneumococcus infections in mice. Proc. Soc. Exper. Biol. and Med., 1937, 36, 148.

(c) Gross, P., and Cooper, F. B., Efficacy of paminobenzenesulfonamide in experimental Type III pneumococcus pneumonia. Proc. Soc. Exper. Biol. and Med., 1937, 36, 225.

10. (a) Heinzelman, J. H., Hadley, P. B., and Mellon, $R$. R., The use of $p$-aminobenzene sulfonamide in Type III pneumococcus pneumonia. Am. J. M. Sc., 1937, 193, 759. (b) Sadusk, J. F., Observations on sulfanilamide therapy in pneumonia and meningitis due to Type III pneumococci. New England J. Med., 1938, 219, 787.

11. (a) Bullowa, J. G. M., The Management of the Pneumonias. Oxford University Press, New York, 1937, p. 201.

(b) Bullowa, J. G. M., Correspondence quoted in Mellon, R. R., Gross, P., and Cooper, F. B., "Sulfanilamide Therapy of Bacterial Infections." Charles C. Thomas, Springfield, Ill., and Baltimore, 1938, p. 206.

12. (a) Neufeld, F., and Etinger-Tulczynska, R., Bakterienkapseln und Quellungsreaction. Ztschr. $f$. Hyg. u. Infektionskr., 1933, 114, 769.

(b) Sabin, A. B., Immediate pneumococcus typing directly from sputum by the Neufeld reaction. J. A. M. A., 1933, 100, 1584.

13. Finland, M., and Sutliff, W. D., Immunity reactions of human subjects to strains of pneumococci other than Types I, II, and III. J. Exper. Med., 1933, 57, 95.

14. Marshall, E. K., Determination of sulfanilamide in blood and urine. J. Biol. Chem., 1937, 122, 263.

15. (a) Enders, J. F., and Shaffer, M. F., Studies on natural immunity to pneumococcus Type III. I. The capacity of strains of pneumococcus Type III to grow at $41^{\circ} \mathrm{C}$. and their virulence for rabbits. J. Exper. Med., 1936, 64, 7.

(b) Rich, A. R., and McKee, C. M., The mechanism of a hitherto unexplained form of native immunity to the Type III pneumococcus. Bull. Johns Hopkins Hosp., 1936, 59, 171.

16. Cromwell, H. W., and Centeno, J. A., The reaction of the white blood cells to specific precipitates. J. Immunol., 1929, 17, 53.

17. Finland, M., and Sutliff, W. D., Infections with Pneumococcus Type III and Type VIII. Arch. Int. Med., 1934, 53, 481.

18. Finland, M., Brown, J. W., and Ruegsegger, J. M., Anatomic and bacteriologic findings in infections with specific types of pneumococci, including Types I to XXXII. Arch. Path., 1937, 23, 801.

19. Blake, F. G., Observations on Pneumococcus Type III pneumonia. Ann. Int. Med., 1931, 5, 673.

20. Robertson, O. H., Recent studies on experimental lobar pneumonia. Pathogenesis, recovery, and immunity. J. A. M. A., 1938, 111, 1432. 